\title{
A KÜLFÖLDI TULAJDONÚ VÁLLALATOK EMBERI ERŐFORRÁS MENEDZSELÉSÉNEK JELLEGZETESSÉGEI ÉS SAJÁTOS KONTINGENCIAFAKTORAI KELET-KÖZÉP-EURÓPÁBAN
}

Ahogy azt az innovációs mozgalom atyja, Schumpeter (1950) már a múlt század közepén jelezte, az üzleti életben az innováció a piaci siker kritikus eleme. Jól ismert típusai (termék, technológia, piacok fejlesztése) mellé mára a szervezetek sikeres működését és növekedését segítő új mentális és üzleti modellek jelentősége is felzárkózóban van (Tidd - Bessant, 2013). A folyamatos változások eredményeként így a szervezetek emberi erőforrásai és menedzselésük is a szervezeti versenyképesség kritikus elemeivé váltak (Gomez-Mejia et al., 2014; Torrington et al., 2014). Ahogy arra szakirodalom megállapítások és gyakorlati példák egyaránt rámutatnak, a külföldi cégek leányvállalatai gyakran a helyiekénél fejlettebb (Hiltrop, 1991; Hoós, 2000) és komplexebb (Dowling et al., 2013) emberierőforrás-menedzselési munkát folytatnak. Lewis (2005) vizsgálatai szerint a felzárkózó kelet-közép-európai országok esetében ez a különbség különösen szembeötlő. A szerzők célja e megállapítások ellenőrzése Kelet-Közép-Európában működő leányvállalatokra vonatkozóan. Öt ország, két időszakból (2011/13 és 2015/16) származó adatainak elemzése alapján képet adnak a külföldi tulajdonú cégek emberierőforrás-menedzselésének - a sajátosan érvényesülő kontingenciafaktorok tükrében azonosítható - jellegzetességeiről.

\section{Kulcsszavak: emberierőforrás-menedzsment, Kelet-Közép-Európa, külföldi tulajdonú vállalatok}

$\mathrm{T}$ öbb mint száz éve annak, hogy a fejlett világ országaiban müködő szervezeteknél megjelentek az olyan szakemberek, akik ,,a munkások munka- és életkörülményeinek javításával foglalkoztak" (Gilbersons, 1950, p. 17.). Az elmúlt évtizedek alatt szerepkörük azonban nagyon sokat változott. A HR több évtizedig más - a személyzeti menedzsment (angolul Personnel Management, PM) - megnevezéssel a menedzsment egy segédfunkciójaként ,alapvetően adminisztratív szerepet töltött be" (Ivancevich, 1995, p. 5.).

A múlt század 80-as éveiben különféle befolyásolók hatására a fejlett nyugati világban új szemléletű HR kezdett teret nyerni. Korai képviselői (pl. Drucker, 1973; Fombrun et al. és Beer et al., 1984) már akkoriban rámutattak az adminisztratív feladatokon túli szerepek igényére és feltételrendszerére. Napjainkra a HR sokhelyütt olyan stratégiai funkcióvá vált, aminek fontos szerepe van a szervezeti hatékonyság- és a profitnövelésben, a dolgozói elégedettség javításában, a hozzáadott érték fokozásában (Storey, 1995; Ulrich - Dulebohn, 2015). A modern HR felismerte, hogy a „munkavállaló a szervezetek versenyképességének kritikus erőforrásává vált" (Cleveland et al., 2015, p. 146.).

Kelet-Közép-Európában a második világháború előtt „némi időbeni lemaradással és eltérésekkel ugyan, de fellelhetőek a kapitalista világ vezető országainak gyakorlatához hasonló kezdeti személyzetmenedzselési szerepek" (Karoliny, 2017, p. 39.). E régióban ugyanakkor a szocializmus időszakában a modern HR vonásai csak nyomokban voltak fellelhetők (Brewster et al., 2010). A személyzetmenedzselés itt többnyire szoros állami irányítás alatt állt (Pundziene - Bučiūnienè, 2009; Morley et al., 2016) és adminisztratív jellegü volt, valamint a taylori tudományos vezetés (Scientific Management) elveit és módszereit követte (Kazlakauiste et al., 2013).

Közelítésünkben ,az emberierőforrás-menedzsment azon (irány)elvek, funkciók, rendszerek (pl. toborzás-kiválasztás, teljesítmény- és javadalmazásmenedzsment, képzés-fejlesztés, alkalmazotti kapcsolatok stb.) kölcsönösen egymásra épülő együttese, melynek hatására létrejön, alakul egy-egy szervezet alkalmazotti állománya, azaz humán tőkéje, formálódik tagjainak egyéni és kollektív teljesítménye, magatartása, attitüdje, azaz társas tökéje. Olyan alapvetö szervezeti folyamat és a szervezetek fennmaradása és fejlödése szempontjából kritikus, többszereplös, az egyéni és a kollektiv teljesitményfokozást célzó menedzsmentfunkció, melynek többszörös céljai sok érintett (pl. tulajdonosok, vevők, vonalbeli vezetők, alkalmazottak stb.) elvárásait jelenithetik meg. Gyakorlata pedig kontextusfüggö, azaz a szervezetek külső és belső környezetének jellemzői által befolyásolt vezetői döntések eredménye (Karoliny, 2017, p. 30-31.).

A nemzetköziesedés és a globalizáció hatására megnövekedett az igény a HR nemzetközi aspektusainak azonosítására és vizsgálatára. A korai publikációkban a szerzők (Fayerweather, 1978; Tung, 1981, 2016) föként a kiküldöttek sikeres vagy sikertelen alkalmazásának, alkalmazkodásának a kérdéskörét kutatták.

A külföldi tulajdonú vállalatok száma és a náluk foglalkoztatott dolgozók létszáma a világban egyre nagyobb méreteket ölt. Egyes becslések szerint „a mintegy 82 ezer nagy multinacionális cégnél dolgozók létszáma 2010-ben már meghaladta a 77 millió föt" (Tarique et al., 2016, p.

\footnotetext{
1 Köszönetnyilvánítás:

A szerzők külön köszönetet mondanak a CEEIRT és a nemzetközi Cranet-hálózat magyarországi, lengyelországi, romániai, szerbiai és szlovákiai közös munkatársainak az általuk gyüjtött adatok felhasználásért.
} 
17.). E jelenség legfontosabb okai között említhetjük a kereskedelmi korlátok lebontását, a piacok és a termelés globalizálódását, a demográfiai viszonyok megváltozását és nem utolsó sorban azt, hogy az 1990-es 250 milliárd dollárhoz képest az éves FDI (Foreign Direct Investment) összmennyisége jelentősen megnőtt a világban (Hill, 2013). Miközben 2007-ben, a globális válság előtt ez az érték már a kétezermilliárd dollárhoz közelített, a későbbi „számos visszaesés után 2015-re még mindig nem éri el a 1.800 milliárdos szintet" (WIR, 2016, p. 3.).

Míg a 80-as évek végén az FDI értéke a kelet-középeurópai régióban szinte jelentéktelen volt, ez az érték mára közel ötszázmilliárd eurónál tart. A fent bemutatott tendenciák az 1. táblázatban láthatóak szerint, a tanulmányban vizsgálandó öt ország tekintetében is erőteljesen érvényesülnek. (mezőgazdaság, ipar, szolgáltatás stb.), valamint a szervezeti (méret, versenystratégia stb.) illeszkedés (Karoliny Balogh, 2017). Míg az utóbbi kettő (ágazati hovatartozás és szervezeti méret, stratégiai irány) a hazai cégek jól ismert és elfogadott kontingenciafaktorai, addig a származási ország menedzsmentkultúrája kifejezetten az IHRM sajátos befolyásoló tényezője.

A külföldi tulajdonú cégek, nemzetközi vállalatok esetében a társadalmi, külső befolyásoló tényezők között ugyanis sokak által kimutatott, jelentős szerepe van a származási ország, az anyacég jellemző menedzsmentkultúrájának. Így például az amerikai tulajdonú vállalatok sokkal inkább a központosított, illetve az ún. „best practice" gyakorlatot követik, és kevésbé figyelnek a helyi viszonyokra (Rees - Edwards, 2003; Dicken, 2011) mint

1. táblázat

Az FDI és jelentőségének alakulása a vizsgált öt kelet-közép-európai országban (2008 és 2015)

\begin{tabular}{|l|c|c|c|c|c|c|}
\hline \multirow{2}{*}{ Országok } & \multicolumn{2}{c|}{$\begin{array}{c}\text { A külföldi } \\
\text { tökebefektetések összértéke } \\
\text { (mrd euró) }\end{array}$} & \multicolumn{2}{c|}{$\begin{array}{c}\text { A külföldi tulajdonú cégek } \\
\text { száma }\end{array}$} & \multicolumn{2}{c|}{$\begin{array}{c}\text { Külföldi cégek által foglal- } \\
\text { koztatottak létszáma (fó) }\end{array}$} \\
\cline { 2 - 8 } & $\mathbf{2 0 0 8}$ & $\mathbf{2 0 1 5}$ & $\mathbf{2 0 0 8}$ & $\mathbf{2 0 1 5}$ & $\mathbf{2 0 0 8}$ & $\mathbf{2 0 1 5}$ \\
\hline Lengyelország & 129 & 232 & 68.325 & 83.552 & 1.460 .700 & 1.747 .811 \\
\hline Magyarország & 64 & 86 & 28.987 & 27.096 & 579.633 & 653.132 \\
\hline Románia & 50 & 64 & 44.022 & 41.172 & 1.138 .000 & 1.228 .000 \\
\hline Szerbia & 14 & 25 & 1.118 & 2.400 & 178.000 & 320.000 \\
\hline Szlovákia & 28 & 41 & 24.158 & 29.857 & 600.000 & 448.282 \\
\hline Összesen & 285 & 448 & 112.347 & 83.552 & 2.495 .633 & 4.397 .225 \\
\hline
\end{tabular}

Források: WIR (2016): World Investment Report 2016. United Nations, New York, Foreign Owned Companies in Hungary (2008-2014) http://statinfo. ksh.hu/Statinfo/haViewer.jsp?lang=en (letöltve 2016. December 10.) ; Poland in Figures 2015, (2015), Zakład Wydawnictw Statystycznych, Warsaw; National Bank of Slovakia (2015) Preliminary data.http://www.nbs.sk/sk/statisticke-udaje/statistika-platobnej-bilancie/priame-zahranicne-investicie (Letöltve: 2017. Január 20.); National Bank of Romania (2016): Foreign Direct Investment in Romania in 2015. Bucharest: National Bank of Romania; Foreign Direct Investment (FDI) in Romania in 2009. (2009):Bucharest: National Bank of Romania, SIEPA (Serbia Investment and Export Promotion Agency) (2014): Beograd

Az előbbiekben vázoltak hívták életre tehát a $H R$ nemzetközi változatát, a nemzetközi emberieröforrás-menedzsmentet (International Human Resource Management/IHRM), avagy a nemzetközi vállalatok gyakorlatában megvalósuló emberierőforrás-menedzsmentet (Dowling - Schuler, 1990; Brewster - Hillar, 1999; Evans et al., 2002; Fang et al., 2017). Az IHRM Dowling és szerzőtársai (2013, p. 4-5.) szerint annyiban különbözik az ún. hazai (domestic) modelltől, hogy „,több HR-tevékenységet foglal magában, szélesebb perspektívájú, jobban bevonódik az egyes alkalmazottak (pl. külföldi kiküldöttek) személyes életébe, többféle eredetü munkavállalókkal (hazai, külföldi) foglalkozik, többféle külső befolyásolótól függ és nagyobb mértékü a bizonytalansága".

A környezeti kontextus jelentőségét hangsúlyozó szerzök (köztük föként az európaiak, élükön Brewster et al., 2004; Poór et al., 2017) a befolyásolók sokaságához való illesztés igényét három fö tényezőcsoporthoz kötve tárgyalják. Ezek: a társadalmi (intézményi és kulturális jellemző), a szektorális (magán-, illetve közszféra) és ágazati a más országból érkezettek. A japán és ázsiai eredetű cégeknél jóval magasabb az ,expat”-ok aránya. Az északi eredetű leányvállalatoknál jóval fontosabb a megegyezés és a tárgyalás, mint más régiókban. A német eredetűek jellemzően az ún. olajozott gépezet modelljét követik. A menedzsmentkultúra-osztályozások (Brewster et al., 2010) azt sugallják, hogy a HR-ben jelentős különbségek figyelhetők meg az eltérő menedzsmentkultúrából érkező cégek esetén. Az északi, a germán és a latin kultúrából érkező cégek pl. jobban elfogadják a szakszervezeteket. Az angolszász cégeknél a HR teljesítménymenedzsment szerepe kiemelten fontos, míg az ázsiaiaknál a kiválasztás, a toborzás és a személyzetfejlesztés a hangsúlyos. Az ösztönzés minden menedzsmentkultúránál kiemelt jelentőségü, hiszen ennek jelentős hatása van a leányvállalat nyereségességére. A kelet-közép-európai eredetü multinacionális vállalatoknál az empirikus vizsgálatokon alapuló sajátos orientáció megállapítása még várat magára.

Lewis (2005) meglátása szerint a Kelet-Közép-Európában megtelepedő multinacionális cégek érkezésüktől 
kezdve kiemelkedően fontosnak tartották a körültekintő és megfontolt emberierőforrás-menedzselési stratégiát. Csillag (2014) megállapítása szerint pedig ehhez kapcsolódóan magukkal hozták saját emberierőforrás-menedzselési gyakorlataikat. Fontos kérdésként fogalmazódik meg tehát, hogy vajon milyen HR-gyakorlatot célszerü követni a világ különböző régióiból érkező cégeknek a kelet-közép-európai országokban? Folytathatják-e a világ más részein bevált gyakorlataikat, vagy milyen sajátos megoldásokat alkalmazzanak ebben a régióban (Horowitz, 2011)? E kérdésekre a komparatív HR-vizsgálatok generális válasza az, hogy „az eltérő kulturális, környezeti és intézményi tényezők természetesen nagymértékben kihatnak az alkalmazandó IHRM-modell jellegére és standardizáltságára" (Thomas - Lazarova, 2014; Rowley et al., 2015). Az sem elhanyagolható kérdés, hogy ez a gyakorlat örökérvényű vagy időszakról-időszakra változik? Más összehasonlító HR-kutatásokból olyan vélemény is ismert, miszerint „a kelet-közép-európai országok menedzsmentkultúrája nem sokban különbözik a közelmúltban modernizálódott nyugati országokétól (Portugália és Írország), miközben jelentős elmaradás állapítható meg azok átláthatósága terén" (Brewster - Bennett, 2010, p. 2585.).

Ugyanakkor alig találhatók a szakirodalomban olyan empirikus vizsgálatok, melyek arról adnak számot, hogy:

- vannak-e a kelet-közép-európai régióban müködő külföldi tulajdonú vállalatoknak sajátos emberierőforrás-menedzselési problémái és megoldásai,

- azok mely tipikus és sajátos kontextuális tényezők, milyen kelet-közép-európai jellegzetességek hatására alakulnak és változnak?

E tanulmány fó célja a fenti kérdésekre adható válaszok feltárása és azok minősítést mellőző bemutatása. Munkánknak nem célja tehát az explicit minősítő állásfoglalás. Ugyanakkor megemlítjük, hogy a hazai gyakorlati szakemberek és szerzők (Hoós, 2000; Meleg, 2004; Csath, 2008; Polónyi, 2011; Bogár, 2012) nem mindegyike tekinti a nemzetközi vállalatok helyi leányvállalatinál folyó menedzselési és HR-munkát egyértelmüen sikeres és/vagy pozitívan megítélhető tevékenységnek.

\section{A kutatási modell - hipotézisek}

A tanulmányban bemutatandó kutatás egy olyan hoszszú távú kutatási együttműködés - a Central and Eastern European International Research Team (a továbbiakban CEEIRT) ${ }^{2}$ - része, amely a Közép- és Kelet-Európa (KKE) egyetemeiről származó kutatókat fogja össze, és amelynek célja az átalakuló HR-gyakorlatok és -szerepek vizsgálata a multinacionális vállalatok $(\mathrm{MNV})$ régióbeli leányvállalatainál. Kutatásaink során, annak kezdetétől arra törekszünk, hogy nyomon kövessük a társadalmi-gazdasági változások hatására az MNV-leányvállalatoknál alkalmazott HR-gyakorlatok és -szerepek terén megragadható trendek irányait és jellegét.

A hosszabb távú kutatásokat megalapozó vizsgálataink (Poór - Farkas, 2012, 2014) alapvetően objektív ada- tokra építő, leíró jellegű munkák voltak. A személyes vállalati interjúk és az online válaszadás során a statisztikai elemzés megkönnyítése érdekében az egyes felmérési fordulókban azonos kérdőívet használtunk. Vizsgálatainkat az 1. ábrán látható modellt követve végeztük.

\section{A kutatási modell}

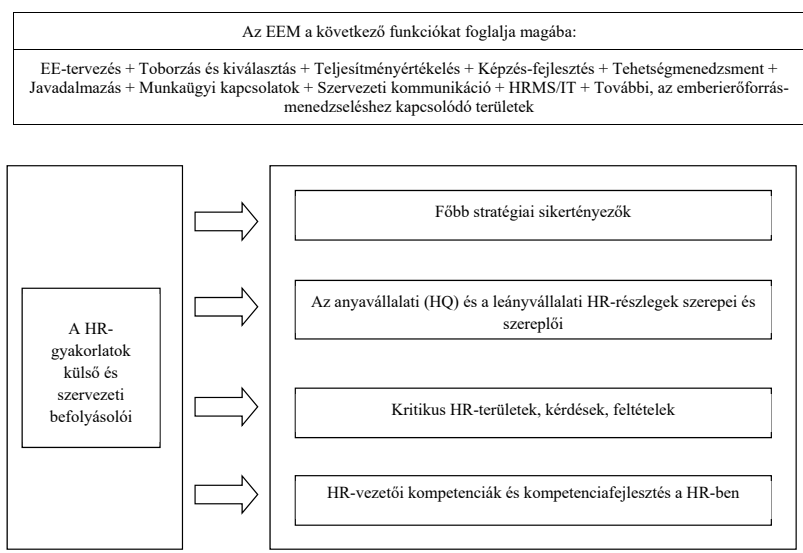

Forrás: Poór J. - Farkas F. (2014): Emberierőforrás-menedzsment külföldi tulajdonú cégek helyi leányvállalatainál Közép- és Kelet-Európában. Pécsi Tudományegyetem, Pécs, 10. o. alapján

A Dunning (1992) által fémjelzett Journal of International Business Research szaklapban megjelent szerkesztőségi cikkben Reeb és szerzőtársai (2012, p. 211.) hangsúlyozzák, hogy a nemzetközi gazdaságtan és a nemzetközi menedzsment területén a kutatás nem könnyü feladat, föként azért, mert „,nagyon ritkán biztosítható a véletlen kiválasztáson alapuló ellenőrzött kutatás". A fenti megállapítás relevanciáját vizsgálataink során magunk is megtapasztaltuk. Érvényes kutatási megállapításokra törekedvén vizsgálatainkban ezért most kizárólag öt olyan ország adatát szerepeltetjük, amelyekben müködő leányvállalatok mindkét időszak felmérésében részt vettek.

A nemzetköziesedéssel összefüggésben a kutatási kérdés általában annak megértését célozza, hogy „hogyan reagál a vállalat a nemzetköziesedésre"? Cikkünk témája szempontjából releváns kérdésként mi azt emeljük ki, hogy a kelet-közép-európai régióban történő terjeszkedésük során a külföldi tulajdonú cégek, multinacionális vállalatok milyen sajátosságokat mutatnak régióbeli emberi erőforrásaik menedzselésében, valamint a választott gyakorlatuk állandó-e vagy valamilyen irányban és mértékben módosul a különféle befolyásoló tényezők függvényében?

Kutatási eredményeink bemutatása a minta specifikálásával kezdődik. A két felmérési időszakban (2011-2013 és 2015-2016) azonos kérdőívvel begyüjtött vizsgálati adatok összehasonlítása ugyanazon öt országból érkezett válaszokra épít ugyan, ám a vizsgálati minta nem tekinthető reprezentatívnak. Az alkalmazott elemzési módszerek: gyakorisági, átlag, szórásvizsgálatok, kereszttábla-elemzések, ANOVA. Az adatok elemzése SPSS 23-as verzióval történt.

- H1: A külföldi cég eredete, az anyavállalat országának (menedzsment) kultúrája befolyásolja a HR-gyakorlatok jellegét. 
Számos kutató ért egyet abban, hogy a nemzeti kultúrák jelentősen befolyásolják a menedzsmentgyakorlatokat (pl. Bartlett - Ghoshal, 2000; Brodbeck et al., 2000; Hofstede, 1980, 1991; Koopman et al., 1999; Poór, 2013). Dicken (2011) szerint a hasonlóság ugyanazon nemzetbeli multik között nagyobb, mint a különbözőség és a különböző transznacionális társaságok megtartják néhány nemzeti sajátosságukat, míg Hazing és Sorge (2003) úgy véli, hogy az anyavállalat menedzsmentje által alkalmazott módszerek meghatározóak a leányvállalatok gyakorlatában is. Fatehi (1996) fontos tényezőként emeli ki, hogy milyen kulturális felfogást követ az anyaországi menedzsment. Mindez szorosan összefügg a Perlmutter (1969) által megfogalmazott ethno-, poli-, regio- és geocentrikus stratégiai orientációval is. Az eredet hatását vizsgálhatjuk a nagyobb menedzsmentkultúrák, pl. angolszász, germán stb. (Brewster et al., 2004; Gupta et al., 2002; Hofstede, 1980; Ronen - Shenkar, 1985) szempontjából. A HRM nézőpontjából alapvető különbség, hogy az amerikai HRM meghatározó tényezője a liberális gazdasági környezet és modelljeire az individualista, teljesítmény-központú megközelítések a jellemzőek, szemben az európai, nemzeti kultúrákon alapuló kevésbé individualista felfogással (Brewster et al., 2004), amely jobban elfogadja a különböző módszerek nemzetekhez, kultúrákhoz kötődő jellegét (Poór, 2013).

- H2: A cég profilja, fö müködési ágazata befolyással van külföldi tulajdonú (leány)vállalatok HR-jellemzőire és -gyakorlatára (Hiltrop, 1991).

- H3: A külföldi tulajdonú cégek, (leány)vállalatok mérete (foglalkoztatottainak száma) nem befolyásolja az MNV-k leányvállalatainak HR-jellemzőit és -gyakorlatát.

A különböző belső szervezeti tényezőknek (mint például a szervezet mérete, az iparág, amelyben müködik vagy a tulajdonosi kör) hatásuk van a különböző HR-változókra, azaz a HRM müködésére (Dowling et al., 2013; Karoliny - Poór, 2013; Lawler, 2006; Paauwe, 2004; Poór, 2013; Poór et al., 2014c, 2015); számos kutatás támasztja alá azt, hogy a HR-rendszerekben mutatkozó különbségek jelentős mértékben a szervezeti mérettől függnek (Poór, 2013).

\section{A minták vizsgált kontingenciafaktorok szerinti megoszlása}

Mint azt már említettük, jelen vizsgálat tárgyát öt kelet-közép-európai országban működő, azaz magyarországi, lengyel, román, szerb és szlovákiai, de ott külföldi tulajdonban lévő leányvállalatok képezik. A részt vevő szervezetek számának felmérési periódusonkénti alakulását a 2. táblázat mutatja. E szerint megállapítható, hogy a mintában a legnagyobb arányt mindkét vizsgált időszakban a magyarországi és a lengyel szervezetek képviselik.
2. táblázat

A felmérésekben részt vevő külföldi tulajdonú cégek országonkénti száma

\begin{tabular}{|c|c|c|}
\hline Országok & $\mathbf{2 0 1 1 - 2 0 1 3}$ & $\mathbf{2 0 1 5 - 2 0 1 6}$ \\
\hline Magyarország & 118 & 90 \\
\hline Lengyelország & 53 & 57 \\
\hline Románia & 34 & 37 \\
\hline Szerbia & 19 & 31 \\
\hline Szlovákia & 30 & 17 \\
\hline Összes & 254 & 232 \\
\hline
\end{tabular}

Forrás: a szerzők saját szerkesztése

A mintabeli cégek által foglalkoztatottak számáról elmondható, hogy míg az első vizsgálati periódusban összesen 246.269 föt, a második terminusban 306.701 dolgozót foglalkoztattak a vizsgált vállalatok.

A válaszadó szervezetek anyavállalatainak országainál már az első vizsgálat palettája is széles. Olyan országokat foglal magában, mint Belgium, Horvátország, Ciprus, Csehország, Németország, Görögország, Írország, Luxemburg, Mexikó, Oroszország, Dél-Afrika, Argentína, Belize, Kína, Dánia, Hollandia, India, Japán, Svédország, Egyesült Államok. A második vizsgálatnál már olyan szervezetek is megjelentek, amelyeknek anyavállalataik Spanyolországban, Litvániában, Dél-Koreában voltak megtalálhatók.

Az anyavállalati központok földrajzi elhelyezkedése alapján a válaszadókat a különböző kultúrakutatások (Bakacsi, 2014; Brodbeck et al., 2000; Gupta et al., 2002; Hofstede, 1980; Inglehart - Baker, 2000; Koopman et al., 1999; Ronen - Shenkar, 1985) és az összehasonlító közgazdaságtan (Amable, 2003; Hall - Soskice, 2001; Psychogios - Wood, 2010) erre vonatkozó eredményeire támaszkodva, a következő hat menedzsmentkultúrába soroltuk: az északi, a germán, a latin, az angolszász, a kelet-európai és az ázsiai, melyek mintabeli részarányát a 3. táblázat adatai mutatják.

3. táblázat

A menedzsmentkultúra-típusok részaránya a két felmérési fordulóban (\%)

\begin{tabular}{|c|c|c|}
\hline Menedzsmentkultúra & 2011-2013 & 2015-2016 \\
\hline északi & 7 & 3 \\
\hline germán & 45 & 42 \\
\hline latin és dél-európai & 14 & 7 \\
\hline angolszász & 23 & 37 \\
\hline kelet-európai & 7 & 9 \\
\hline ázsiai & 4 & 2 \\
\hline
\end{tabular}

Forrás: a szerzők saját szerkesztése

A vizsgált mintákban a germán és az angolszász menedzs- 
mentkultúrájú cégek aránya a meghatározó. A hagyományos multinacionális vállalatok (északi, amerikai, japán) mellett a második fordulóban már feltünnek az ún. feltörekvő vagy más szóval átalakuló(transitional) országok (pl. Lettország, Litvánia, Lengyelország) cégei is.

A vizsgálatokban részt vevő vállalatok ágazatok szerinti megoszlását a 4 . táblázat mutatja.

4. táblázat

A minta ágazatok szerinti megoszlása a vizsgálati időszakokban (\%)

\begin{tabular}{|c|c|c|c|c|}
\hline & \multicolumn{4}{|c|}{ Ágazat } \\
\hline Év & Ipar & Kereskedelem & Szolgáltatás & Egyéb \\
\hline $2011-2013$ & 46 & 17 & 35 & 2 \\
\hline $2015-2016$ & 34 & 17 & 42 & 7 \\
\hline
\end{tabular}

Forrás: a szerzők saját szerkesztése

Az ágazati besorolás szerint 2011-2013-as felmérésben a vállalatok majdnem fele (46\%) volt ipari cég, 35\%-uk pedig a szolgáltatások piacán, 17\%-uk a kereskedelemben müködött.

2015-2016-ban a működési terület szerinti besorolás némileg módosult, hiszen 42\%-os részesedéssel a szolgáltatás (benne $21 \%$ pénzügyi, 17\% egyéb és 4\% belső üzleti szolgáltatással) tört élre, amit az ipar 34\%-os részesedése követ. A kereskedelem részaránya pedig változatlanul $17 \%$.

A felmérési fordulók mintáiban szereplő külföldi tulajdonú cégek, (leány)vállalatok foglalkoztatotti létszámmal kifejezett méret szerinti megoszlása az 5. táblázatban látható. E szerint a vizsgálatban szereplö külföldi tulajdonú cégek mintegy fele 250 főnél kevesebb alkalmazottal dolgozik, ám legalább negyedük már nagyobb, mintegy ötödük pedig kifejezetten nagyméretű szervezet.

5. táblázat

A minta szervezeti méret (foglalkoztatotti létszám) szerinti megoszlása (\%)

\begin{tabular}{|c|c|c|}
\hline Foglalkoztatottak létszáma (fö) & $\mathbf{2 0 1 1 - 2 0 1 3}$ & $\mathbf{2 0 1 5 - 2 0 1 6}$ \\
\hline 250 fő alatt & 48 & 45 \\
\hline $251-1000$ & 25 & 28 \\
\hline $1001-2000$ & 15 & 11 \\
\hline $2001-5000$ & 9 & 11 \\
\hline 5001 fölött & 3 & 5 \\
\hline
\end{tabular}

Forrás: a szerzők saját szerkesztése

A felmérés a külföldi tulajdonú cégeket, leányvállalatokat az aktuálisan követett stratégiai fejlödési irányuk szerint is azonosította. E szempontjából a válaszadók a következő alternatívák közül választhattak:

- növekedés, piacbővítés, portfólióbővítés,

- stabilitás, hatékonyságjavítás, nyereségmegtartás, al-

kalmazkodás a piaci helyzethez,

- létszámcsökkentés, racionalizálás,

- egyéb stratégiák.
6. táblázat

A válaszadók stratégiai irány szerinti megoszlása (\%)

\begin{tabular}{|l|c|c|}
\hline A vállalat stratégiai iránya & 2011-2013 & 2015-2016 \\
\hline növekedés, piacbővítés & 59 & 71 \\
\hline stabilitás megőrzése & 37 & 25 \\
\hline méretcsökkentés & 3 & 3 \\
\hline egyéb & 1 & 0 \\
\hline összesen & 100 & 100 \\
\hline
\end{tabular}

Forrás: a szerzők saját szerkesztése

Kutatási programunk 2008-as, pilot verziójában - a gazdasági válság kezdetekor - e kérdésre a stabilitás megörzése (34\%) és a méretcsökkenés $(21 \%)$ volt a jellemző válasz. Ahogy az a 6. táblázat adataiból jól látszik, a most elemzett kutatásunk első periódusában - a válságból való kilábalás időszakában - a szervezetek többségénél már a növekedés és a piacbővítés dominál, a második felmérési fázisban pedig ez utóbbi válik meghatározóvá.

\section{Sikertényezők, kritikus HR-szerepek, szereplők és jellemzők}

A stratégiai irányok megvalósításának legfontosabb sikertényezői közül a válaszadók az első, legfontosabb elemnek mindkét periódusban a biztositható minöségi munkaeröt jelölték, az első forduló második helyén álló optimális üzemméret szerepét a második felmérésben a menedzsment színvonala veszi át (lásd 7. táblázat). A legkisebb jelentőségűnek minősített sikertényezők között mindkét periódusban az alacsony munkaerö-költséget és a pénzügyi források hozzáférhetőségét találjuk.

7. táblázat

A stratégiai sikertényezők fontosságának alakulása a két időszakban (\%)

\begin{tabular}{|l|c|c|}
\hline Sikertényezők & 2011-2013 & 2015-2016 \\
\hline a biztosítható minőségi munkaerő & 24 & 24 \\
\hline optimális üzem/szervezeti méret & 20 & 17 \\
\hline a pénzügyi források hozzáférhetősége & 10 & 11 \\
\hline a menedzsment színvonala & 15 & 20 \\
\hline termelési technológia & 16 & 14 \\
\hline alacsony munkaerő-költségek & 12 & 12 \\
\hline egyéb & 3 & 2 \\
\hline összesen & 100 & 100 \\
\hline
\end{tabular}

Forrás: a szerzők saját szerkesztése

Kutatásunk a HR-szerepek és -szereplők témakörében a kérdőív-kitöltőket először a vállalati központ (HQ) $H R$ 
részlegének a leányvállalati $\mathrm{HR}$ irányításában betöltött jellemző szerepéről kérdezte úgy, hogy a 8 . táblázatban is látható állítások közül kellett a rájuk legjellemzőbbet kiválasztaniuk.

8. táblázat

A vállalati központok HR-részlegeinek jellemző szerepei szerinti megoszlás (\%)

\begin{tabular}{|l|c|c|}
\hline $\begin{array}{l}\text { A központi HR-részlegek } \\
\text { jellemzö szerepei }\end{array}$ & 2011-2013 & 2015-2016 \\
\hline $\begin{array}{l}\text { nagymértékü döntési és végrehajtási } \\
\text { szabadságot ad (decentralizáció) }\end{array}$ & 20 & 28 \\
\hline $\begin{array}{l}\text { általános irányelveket és } \\
\text { keretrendszert biztosít }\end{array}$ & 48 & 39 \\
\hline $\begin{array}{l}\text { részletes HR-modell, személyzeti } \\
\text { politika, folyamatok és szabályozás } \\
\text { megadása }\end{array}$ & 25 & 26 \\
\hline $\begin{array}{l}\text { minden kevésbé jelentős HR-döntés } \\
\text { forrása, beleszólás (centralizáció) }\end{array}$ & 7 & 7 \\
\hline összesen & 100 & 100 \\
\hline
\end{tabular}

Forrás: a szerzők saját szerkesztése

A vizsgált periódusok közös jellemzője, hogy a tipikusan érvényesülő vállalatközponti HR-szerep az általános irányelvek és a keretrendszer biztosítása, miközben a centralizáció, a legkevésbé jellemzőnek tartott megoldás. Bár a válaszadók negyede szerint a részletes HR-modell, a személyzeti politika, a folyamatok és szabályozás forrása is a központi HR-részleg, ugyanakkor a második periódusban a decentralizáció fokozódását érzékelők köre is növekszik és meghaladja a válaszadók negyedét.

A HR szervezeti helye, jelentősége szempontjából fontos kérdés, hogy kik és hogyan hozzák meg a HR kulcsterületeire vonatkozó döntéseket. Vizsgálatunk a következő HR-területekre terjedt ki: emberierőforrás-tervezés, toborzás, kiválasztás, teljesítményértékelés, személyzetfejlesztés, tehetséggondozás, ösztönzés és juttatások, munkaügyi kapcsolatok, dolgozói (belső) kommunikáció, HRIS (informatika), munkavédelem, munkaegészségügy, egyéb. A jellemző döntéshozók közül a helyi vezetést, a helyi HR-részleget, illetve a helyi vezetés és a helyi HR-részleg közötti konzultáción alapuló, valamelyik fél általi döntést lehetett választani.

A 2011-2013-as felmérés válaszai vegyes képet mutattak. A helyi vezetés döntési felelőssége alapvetően a teljesítményértékelésben, az ösztönzés és juttatásokban nyilvánult meg. A lokális irányítás a helyi HR véleményét kikérve dönt a személyzetfejlesztésben, valamint az emberierőforrás-tervezésben. Alapvetően a helyi HR kezdeményezésére, de a helyi vezetéssel konzultálva valósult meg például a munkaerő toborzása, a kiválasztás, a belső kommunikáció. Többségében a helyi HR döntött a munkavédelemröl, vagy az informatikáról. A 2015-2016-os válaszok szerint a javadalmazásról és az értékelésekről szóló döntéseken kívül minden másról alapvetően a helyi HR határozott.

A vizsgálatunk arra is kitért, hogy az egyes HR-funkciók végrehajtásához a cégek milyen mértékben vették igénybe a külső HR-szolgáltatók/tanácsadók segítségét. 2011-2013-ban a válaszolók főként a toborzás és a személyzetfejlesztés feladatait végeztették külső HR-szolgáltatókkal. A 2015-2016-os válaszadók többsége alapvetően saját erőforrásaival próbálta megoldani a HR-funkcióit, kivéve a munkavédelem területét, ahol e feladathoz szinte minden második leányvállalat változatlanul alkalmaz külső tanácsadót.

A HR szervezeti jelentőségének egyik fontos indikátora a képzési költséghányad mutató értékének alakulása. A vizsgálat során az elemzések arra is kitértek, hogy miképpen alakult az éves képzési keret a bérköltség \%-ban, melybe a 9. táblázat nyújt bepillantást.

\section{9. táblázat \\ A válaszadók képzési költséghányad szerinti megoszlása (\%)}

\begin{tabular}{|l|c|c|}
\hline $\begin{array}{l}\text { Az éves képzési keret } \\
\text { a bérköltség \%-ában }\end{array}$ & 2011-2013 & $\mathbf{2 0 1 5 - 2 0 1 6}$ \\
\hline kisebb 1\%-nál & 26 & 25 \\
\hline $1-3 \%$ & 42 & 44 \\
\hline nagyobb 3\%-nál & 32 & 31 \\
\hline összesen & 100 & 100 \\
\hline
\end{tabular}

Forrás: a szerzők saját szerkesztése

A válaszok alapján megállapítható, hogy a két vizsgált időszakban az 1-3\%-os képzési költséghányad a jellemző szint, ám meglehetősen magas, több mint 30\% azon cégek aránya, ahol a mutató 3\% fölötti értékéről számoltak be, ami e szervezetek esetében az emberi eröforrások versenytényezőnek tekintésére utalnak.

A válaszadóktól az egyes HR területek/funkciók kapcsán azok kritikusságának mértékét kértük kifejezni egy ötfokozatú skála segítségével, ahol az egyes az egyáltalán nem, míg az ötös a teljesen kritikust jelentette. A kritikusság mértékét kifejező átlagokat a 10. táblázat mutatja.

10. táblázat

Kritikus HR-területek (átlagok)

\begin{tabular}{|l|c|c|}
\hline Kritikus HR-területek & $\mathbf{2 0 1 1 - 2 0 1 3}$ & $\mathbf{2 0 1 5 - 2 0 1 6}$ \\
\hline emberierőforrás-tervezés & 2,93 & 2,81 \\
\hline toborzás és kiválasztás & 2,97 & 3,19 \\
\hline teljesítményértékelés & 3,07 & 2,56 \\
\hline képzés és fejlesztés & 2,99 & 2,74 \\
\hline tehetséggondozás & 2,94 & 2,71 \\
\hline javadalmazás és juttatás & 2,85 & 2,74 \\
\hline munkaügyi kapcsolatok & 3,33 & 2,27 \\
\hline kommunikációazalkalmazottakkal & 3,04 & 2,51 \\
\hline egyéb & 2,31 & 2,33 \\
\hline
\end{tabular}

Forrás: a szerzők saját szerkesztése 
2011-2013-ban a kritikusság mértékének mutatója az egyéb területeket leszámítva - a 2,85 -3,33-ig terjedö, 0,5-ös eltérést mutató sávon belül mozgott. A legkevesebb gondot okozó területnek - nem várt módon - a javadalmazást és juttatásokat jelölték, míg a leginkább kritikusnak - szintén meglepő módon - a munkaügyi kapcsolatokat tartották, amit a teljesítményértékelés és az alkalmazotti kommunikáció is 3 feletti átlagértékekkel követ. A 201516-os periódusra a munkaügyi kapcsolatok az élről eltünve a legkevésbé kritikus tényezővé válik, miközben a toborzás-kiválasztás veszi át a szerepét, és szinte minden más HR-terület csaknem egyformán a közepesnél alacsonyabb jelentőségüek közé kerül.

A modellt követve a vizsgálat részét képezte az aktuálisan jellemző HR-kérdések, -feltételek és-eredmények feltárása. A 11. táblázatban felsorolt tényezők cégükre jellemző voltát a válaszadók négyfokozatú skálán jelezhették, melyből átlag- és szórásértékeket számoltunk.

11. táblázat

A jellemző HR-feltételek, -eredmények (átlag, szórás)

\begin{tabular}{|c|c|c|c|c|}
\hline HR-feltételek & Időszakok & $\mathbf{N}$ & Átlag & Szórás \\
\hline \multirow{3}{*}{$\begin{array}{l}\text { könnyen találunk a } \\
\text { munkaerőpiacon fizikai } \\
\text { dolgozókat }\end{array}$} & $2011 / 13$ & 236 & 2,48 & 1,109 \\
\hline & $2015 / 16$ & 207 & 2,14 & 1,033 \\
\hline & Teljes & 443 & 2,32 & 1,086 \\
\hline \multirow{3}{*}{$\begin{array}{l}\text { könnyen találunk a } \\
\text { munkaerőpiacon jól } \\
\text { képzett mủszakiakat }\end{array}$} & $2011 / 13$ & 241 & 2,20 & ,880 \\
\hline & $2015 / 16$ & 214 & 2,01 & 880 \\
\hline & Teljes & 455 & 2,11 & ,884 \\
\hline \multirow{3}{*}{$\begin{array}{l}\text { a legtöbb munkakörben } \\
\text { nem jelent gondot az } \\
\text { idegennyelv-tudás }\end{array}$} & 2011/13 & 243 & 2,47 & ,967 \\
\hline & $2015 / 16$ & 221 & 2,66 & ,913 \\
\hline & Teljes & 464 & 2,56 & ,946 \\
\hline \multirow{3}{*}{$\begin{array}{l}\text { könnyen meg tudjuk } \\
\text { tartani a tehetségeket }\end{array}$} & $2011 / 13$ & 247 & 2,64 & 890 \\
\hline & 2015/16 & 221 & 2,48 & ,784 \\
\hline & Teljes & 468 & 2,56 & 845 \\
\hline \multirow{3}{*}{$\begin{array}{l}\text { minden munkakörben } \\
\text { versenyképes jövedelmet } \\
\text { tudunk biztosítani }\end{array}$} & $2011 / 13$ & 246 & 2,69 & 845 \\
\hline & $2015 / 16$ & 218 & 2,67 &, 803 \\
\hline & Teljes & 464 & 2,68 &, 825 \\
\hline \multirow{3}{*}{$\begin{array}{l}\text { a szakszervezetek befo- } \\
\text { lyása jelentős }\end{array}$} & 2011/13 & 237 & 1,72 & ,934 \\
\hline & $2015 / 16$ & 213 & 1,62 &, 820 \\
\hline & Teljes & 450 & 1,67 & ,882 \\
\hline
\end{tabular}

Forrás: a szerzők saját szerkesztése

A táblázatbeli eredmények szerint a szervezetek egyre nehezebben tudnak a munkaerőpiacon jól képzett munkaerőt találni, legyen szó akár fizikai, akár müszaki dolgozóról. Bár a tehetségmegtartó képességüket még elég erősnek vélik, ám az annak ellenére romló tendenciát mutat, hogy a válaszadók a minden munkakörben versenyképes jövedelembiztosító gyakorlatukat tartják a legerőteljesebbnek. Annak ellenére vélik ezt így, hogy ebben a szakszervezetek alig játszanak szerepet, hiszen a szakszervezetek befolyása nemcsak alacsony szintü, de még csökkenő mértékű is. Jellemzően kismértékű szórásokkal találkozunk, ami azt mutatja, hogy a feltételekkel kapcsolatban viszonylag homogén volt a válaszadók véleménye.

A vizsgálat a HR-vezetők kulcskompetencia-csoportjait is igyekezett feltárni. A jelölhető HR-vezetői kulcskompetenciák a következők voltak: üzleti ismeretek (értéklánc, értékteremtés), stratégiai hozzájárulás (kultúramenedzselés, gyors változtatás, stratégiai döntéshozás), a személyes hitelesség (eredményesség, hatékony kapcsolatok, kommunikációs képességek), a HR-szolgáltatások (toborzás-kiválasztás, képzés, TÉR, HR-mérés stb.) nyújtása, az információs technológia használata és az idegen nyelvü kommunikáció.

A HR-vezetői kompetenciák fontossági rangsora élén a személyes hitelesség áll 85\%-os támogatással. Ezt követöen azonos aránnyal (70-70\%) szerepel az üzleti ismeretek birtoklása és az idegen nyelvű kommunikáció képessége. A válaszadó cégek valamivel több mint $40 \%$-ánál az információs technológia használatát 2011-2013-ban csak kis mértékben vélték a meghatározó HR-kompetenciák közé tartozónak. A 2015/2016-os felmérésben ez az arány pedig még alacsonyabb, csupán $15 \%$.

Végezetül felmérésünk a HR-vezetőktől elvárt kompetenciák mellett az egyéni HR-kompetenciafejlesztés módozatait is vizsgálta. A 12. táblázatban is látható egyes módozatok jelentőségét ötfokozatú skálán lehetett értékelni.

12. táblázat

A HR területén megvalósuló kompetenciafejlesztési módozatok (átlag, szórás)

\begin{tabular}{|l|c|c|c|c|}
\hline $\begin{array}{l}\text { A HR-kompetencia- } \\
\text { fejlesztés módjai }\end{array}$ & & N & Átlag & Szórás \\
\hline \multirow{3}{*}{$\begin{array}{c}\text { informális tanulás a HR- } \\
\text { részlegen }\end{array}$} & 2011 & 241 & 3,18 & 1,238 \\
\cline { 2 - 5 } & 2015 & 174 & 3,07 & 1,364 \\
\cline { 2 - 5 } & Teljes & 415 & 3,14 & 1,292 \\
\hline \multirow{3}{*}{$\begin{array}{l}\text { informális tanulás másik } \\
\text { leányvállalat HR-részlegén }\end{array}$} & 2011 & 231 & 2,16 & 1,267 \\
\cline { 2 - 5 } & 2015 & 165 & 2,29 & 1,254 \\
\cline { 2 - 5 } & Teljes & 396 & 2,21 & 1,262 \\
\hline \multirow{3}{*}{$\begin{array}{c}\text { informális tanulás az } \\
\text { anyavállalatnál }\end{array}$} & 2011 & 245 & 2,57 & 1,255 \\
\cline { 2 - 5 } & 2015 & 166 & 2,69 & 1,279 \\
\cline { 2 - 5 } & Teljes & 411 & 2,62 & 1,264 \\
\hline \multirow{3}{*}{$\begin{array}{l}\text { helyi HR-képzés és } \\
\text { fejlesztés }\end{array}$} & 2011 & 245 & 3,22 & 1,198 \\
\cline { 2 - 5 } & 2015 & 166 & 3,31 & 1,126 \\
\cline { 2 - 5 } & Teljes & 411 & 3,26 & 1,169 \\
\hline \multirow{3}{*}{$\begin{array}{l}\text { HR-képzés és -fejlesztés az } \\
\text { anyavállalatnál }\end{array}$} & 2011 & 239 & 2,69 & 1,392 \\
\cline { 2 - 5 } & 2015 & 206 & 2,50 & 1,252 \\
\cline { 2 - 5 } & Teljes & 445 & 2,60 & 1,331 \\
\hline
\end{tabular}

Forrás: a szerzők saját szerkesztése

A válaszok alapján megállapítható, hogy a tipikusan - a közepes szintet meghaladóan - alkalmazott módszer: a he- 
lyi szinten megoldott HR-képzés és -fejlesztés, valamint a HR-részlegeken megvalósuló informális tanulás. Eközben a kismértékben alkalmazott szintet éppen csak meghaladó gyakorlatnak a más leányvállalatok gyakorlatába történő betekintés mutatkozott. Az anyavállalati HR-képzésnek a formális és az informális módjai is csupán a közepes szint alatti jelentőséget érnek el a vizsgált leányvállalatoknál. E tekintetben a két időszakban végzett kutatás eredményei alig térnek el egymástól.

A felmérésekben részt vevő szervezetek stratégiai irányait, HR-szerepeit és -szereplöit, valamint kritikus emberierőforrás-menedzselési feltételeit és jellemzőit bemutató leíró statisztikai áttekintés után lássuk a három hipotézis alátámasztását szolgáló elemzési módszereket és eredményeket!

\section{Hipotézisellenőrzés - következtetések}

A következőkben bemutatjuk, hogy milyen érvényességet mutatnak hipotéziseink (H1-H3).

- H1: A külföldi cég eredete, az anyavállalat országának (menedzsment) kultúrája befolyásolja a vizsgált öt országban folytatott HR-gyakorlatok jellegét.

Az ANOVA vizsgálatok alapján megállapítható, hogy habár szignifikánsan egyik jellemző HR-feltétel kapcsán sem tekinthetők eltérőnek a gyakorlatok, de tendenciaszerűen megjelenik, hogy míg az ázsiai kultúrában müködő anyacégek könnyebben találnak fizikai munkaerőt, addig ez a germán, illetve az angolszász kultúrájú anyavállalattal rendelkező szervezetek esetében jelentős ki-

ANOVA a kritikus HR-tényezők viszonylatában (2011-2016) $(p=0,05)$

\begin{tabular}{|c|c|c|c|c|c|c|}
\hline Kritikus HR-funkciók & Irányok & Négyzetes összeg & df & Variancia & $\mathbf{F}$ & Sig. \\
\hline \multirow{3}{*}{$\begin{array}{l}\text { kritikus HR-területek - } \\
\text { emberierőforrás-tervezés }\end{array}$} & csoportok közötti & 22,448 & 6 & 3,741 & 1,837 & ,091 \\
\hline & csoporton belüli & 843,367 & 414 & 2,037 & & \\
\hline & teljes & 865,815 & 420 & & & \\
\hline \multirow{3}{*}{$\begin{array}{l}\text { kritikus HR-területek - toborzás és } \\
\text { kiválasztás }\end{array}$} & csoportok közötti & 16,879 & 6 & 2,813 & 1,465 & , 188 \\
\hline & csoporton belüli & 842,825 & 439 & 1,920 & & \\
\hline & teljes & 859,704 & 445 & & & \\
\hline \multirow{3}{*}{$\begin{array}{l}\text { kritikus HR-területek - } \\
\text { teljesítményértékelés }\end{array}$} & csoportok közötti & 6,552 & 6 & 1,092 & ,558 & ,763 \\
\hline & csoporton belüli & 821,308 & 420 & 1,955 & & \\
\hline & teljes & 827,859 & 426 & & & \\
\hline \multirow{3}{*}{$\begin{array}{l}\text { kritikus HR-területek - képzés és } \\
\text { fejlesztés }\end{array}$} & csoportok közötti & 10,641 & 6 & 1,774 & 1,030 & ,405 \\
\hline & csoporton belüli & 752,296 & 437 & 1,722 & & \\
\hline & teljes & 762,937 & 443 & & & \\
\hline \multirow{3}{*}{$\begin{array}{l}\text { kritikus HR-területek - } \\
\text { tehetséggondozás }\end{array}$} & csoportok közötti & 7,252 & 6 & 1,209 &, 706 & ,645 \\
\hline & csoporton belüli & 695,552 & 406 & 1,713 & & \\
\hline & teljes & 702,804 & 412 & & & \\
\hline \multirow{3}{*}{$\begin{array}{l}\text { kritikus HR-területek - } \\
\text { javadalmazás és juttatás }\end{array}$} & csoportok közötti & 4,172 & 6 & 695 & ,413 &, 870 \\
\hline & csoporton belüli & 730,050 & 434 & 1,682 & & \\
\hline & teljes & 734,222 & 440 & & & \\
\hline \multirow{3}{*}{$\begin{array}{l}\text { kritikus HR-területek - munkaügyi } \\
\text { kapcsolatok }\end{array}$} & csoportok közötti & 8,092 & 6 & 1,349 &, 742 & ,616 \\
\hline & csoporton belüli & 737,763 & 406 & 1,817 & & \\
\hline & teljes & 745,855 & 412 & & & \\
\hline \multirow{3}{*}{$\begin{array}{l}\text { kritikus HR-területek - } \\
\text { kommunikáció az alkalmazottakkal }\end{array}$} & csoportok közötti & 9,203 & 6 & 1,534 & ,817 &, 557 \\
\hline & csoporton belüli & 797,461 & 425 & 1,876 & & \\
\hline & teljes & 806,664 & 431 & & & \\
\hline \multirow{3}{*}{ kritikus HR-területek - egyéb } & csoportok közötti & 9,914 & 4 & 2,479 & 1,420 & ,258 \\
\hline & csoporton belüli & 41,879 & 24 & 1,745 & & \\
\hline & teljes & 51,793 & 28 & & & \\
\hline
\end{tabular}


hívást jelent. A kelet-közép-európai kultúrában müködő anyavállalatot maga mögött tudó szervezeteknél a legnehezebb a jól képzett műszaki munkaerőt megtalálni, a tehetségek megtartása azoknál a cégeknél a legkönnyebb, amelyek anyavállalata az északi kultúrákhoz tartozik. A vizsgálatban szereplö cégek esetében az anyavállalat menedzsmentkultúra-típusától függetlenül igaz, hogy a szakszervezetek befolyása igen alacsony. Amíg azonban a legutóbbi megállapítás bizonyára szektorsemleges is, addig az előzőek alakulásában a müködési ág és hely eltérő munkaerő-piaci jellegzetességei is szerepet játszhatnak.

A vizsgált mintákban az tapasztalható, hogy a stratégia sikertényezők közül a minőségi munkaerő a legfontosabb az északi, a germán, a dél-európai, az angolszász és a kelet-közép-európai kultúrákban, míg az ázsiaiban ezt a helyet az optimális üzemméret uralja. A dél-európai és a kelet-közép-európai kultúra képviselői az alacsony munkaerő-költséget jelölték a legjellemzőbbnek. A pénzügyi források hozzáférhetőségét az északi, a germán, az angolszász, az ázsiai kultúrákból érkezők a kevésbé jellemző stratégiai tényezők közé sorolták.

A központi/anyavállalati HR szerepét jellemezve szinte minden kultúratípus válaszadói az általános irányelvek és keretrendszer biztosításában jelölték meg, kivéve a közép-kelet-európai menedzsmentkultúrájú anyavállalatokkal rendelkező cégeket, melyek többségénél a nagymértékü döntési és végrehajtási szabadságról nyilatkoztak a válaszadók.

A kritikus HR-területekre irányuló - a 13. táblázatban olvasható ANOVA vizsgálat - a különböző menedzsmentkultúrák között nem jelzett szignifikáns különbséget.

A különböző menedzsmentkultúrájú anyavállalatokkal rendelkező cégek közötti különbségeket kerestük az alkalmazott HR-kompetenciafejlesztési módokra vonatkozóan is. Habár az ANOVA vizsgálat szignifikáns eltérést nem igazolt, az megállapítható, hogy a HR-kompetenciafejlesztés a HR-részlegen megvalósuló informális tanulás- sal, valamint helyi HR-képzés és -fejlesztés révén valósul meg. Míg az első leginkább a kelet-közép-európai, addig az utóbbi az északi és az angolszász kultúrájú anyavállalatokkal rendelkező szervezeteknél jellemző.

A kritikus HR-vezetői kompetenciák közül az északiak, a germánok, a dél-európaiak és az angolszászok a személyes hitelességet, azaz a jó és hatékony kommunikációt, valamint az idegen nyelvü kommunikációt emelték ki, míg a kelet-közép-európai kultúrát képviselő cégek az üzleti ismereteket tartották fontosnak.

Az előzőekben leírtak alapján megállapítható, hogy a cég eredete, azaz az anyavállalat menedzsmentkultúrája szerinti klaszterek HR-gyakorlatai mutatnak ugyan jól azonosítható sajátosságokat és eltéréseket egyes menedzsmentkultúrák között, a kultúraklaszterekkel való összefüggésekre vonatkozó ANOVA vizsgálatok azonban nem jelzik szignifikánsnak a vizsgált változók közötti kapcsolatokat. Ez azonban nem zárja ki - ahogyan azt láttuk is -, hogy egyes HR-gyakorlatok esetében bizonyos kultúraklaszterek között jól megragadható különbségek legyenek. A H1 hipotézisünk így részben nyert igazolást.

• H2: A cég profilja, fő müködési ágazata befolyással van külföldi tulajdonú (leány)vállalatok HR-jellemzőire és -gyakorlatára.

A két felmérési fordulóban jelölhető sikertényezők (optimális üzemméret, minőségi munkaerő, pénzügyi források elérhetősége, menedzsment színvonala, termelési technológia, alacsony munkaerő-költségek, egyéb) mentén vizsgálódva a 2011-2013-as felmérés válaszai alapján egyik faktor esetében sem tudtunk szignifikáns különbséget igazolni. A 2015-2016-os év esetében viszont több tényező mentén igazolható a különbség. Így míg a pénzügyi források elérhetőségét (Pearson-féle Khi-négyzet:11,011, df:3, szign.:0,012, p<0,05) az ipari cégeknek csupán 19\%-a jelöli a legfontosabb sikertényezői között, addig $a$ szolgáltatócégeknek majdnem a duplája (39,2\%-a), a kereskedelmi szervezeteknek pedig ennél is jelentősebb hányada (43,6\%). Hasonlóan eltérőek

14. táblázat

ANOVA a kritikus HR-tényezők viszonylatában $(2011-2013)(p=0,05)$

\begin{tabular}{|c|c|c|c|c|c|c|}
\hline Kritikus HR-funkciók & Irányok & Négyzetes összeg & df & Variancia & $\mathbf{F}$ & Sig. \\
\hline \multirow{3}{*}{ emberierőforrás-tervezés } & csoportok közötti & 23,975 & 3 & 7,992 & 3,853 & ,010 \\
\hline & csoporton belüli & 474,927 & 229 & 2,074 & & \\
\hline & teljes & 498,901 & 232 & & & \\
\hline \multirow{3}{*}{ toborzás és kiválasztás } & csoportok közötti & 16,721 & 3 & 5,574 & 2,817 & 040 \\
\hline & csoporton belüli & 463,010 & 234 & 1,979 & & \\
\hline & teljes & 479,731 & 237 & & & \\
\hline \multirow{3}{*}{ képzés és fejlesztés } & csoportok közötti & 17,184 & 3 & 5,728 & 3,100 & 027 \\
\hline & csoporton belüli & 439,779 & 238 & 1,848 & & \\
\hline & teljes & 456,963 & 241 & & & \\
\hline
\end{tabular}


a leányvállalatok a termelési technológia mint sikertényező megítélésében (Pearson-féle Khi-négyzet:42,797, df: 3, szign.:0,00, p<0,05), mely értelemszerü. Ezt az iparban müködő szervezetek 67,1\%-a, a kereskedelmi cégek 30,8\%-a, míg a szolgáltatóvállalatok 19,6\%-a jelölte sikertényezőnek. Az alacsony munkaerö-költségeket vizsgálva is szignifikáns különbséget találtunk (Pearson-féle Khi-négyzet:12,893, df:3, szign.:0,005, p<0,05). Azok aránya, akik ezt sikertényezőnek jelölték ugyan alacsony, ám közöttük ágazati különbségek azonosíthatók. Míg az iparvállalatok 3,8\%-a, a kereskedelmi szervezetek $5,1 \%$-a, és a szolgáltatási szektorban müködők 6,2\%-a vélte sikerfaktornak ezt a változót.

A kritikus HR-területeket az ágazatok dimenziójában és az adott vizsgálati periódusok tükrében is megvizsgálva, a 2011-2013-as évben több faktor esetében is kimutatható volt, hogy ágazatok szerint eltérőek a vélemények. Azokat az ANOVA eredményeket, ahol a kritikus tényezők viszonylatában igazolható a szignifikáns különbség a 14. táblázat tartalmazza. Mindhárom változó esetében a kereskedelemben müködő szervezetek vélték leginkább kritikusnak az azonosított tényezőket. 2015-2016-ban viszont e kérdésben az ágazatok szerint már nem lehetett szignifikáns különbséget kimutatni.

A vizsgálatok azt mutatják, hogy a központi HR szerepét tekintve nem különböznek szignifikánsan egymástól a különböző ágazatokban tevékenykedő cégek, hiszen a válaszadók szerint jellemzően az általános HR-irányelvek és -keretrendszer kialakításának meghatározásában van szerepe a központi/anyavállalati HR-szervezetnek (Pearson-féle Khi-négyzet:14,393 df: 9, szign.:0,109 p>0,05.)

A HR-vezetôi kompetenciákat vizsgálva valamennyi ágazatban a személyes hitelességet és az idegen nyelvü kommunikáció fontosságát emelték ki továbbra is a válaszadók.

Az előzőekben leírtak alapján a H2 hipotézist szintén részben tartjuk igazoltnak.

- H3: A külföldi tulajdonú cégek, (leány)vállalatok mérete (foglalkoztatottainak száma) nem befolyásolja az MNV-k leányvállalatainak HR-jellemzőit és -gyakorlatát.

Először itt is a jellemző sikertényezők (optimális üzemméret, a minőségi munkaerő, a pénzügyi források hozzáférhetősége, a menedzsment színvonala, a termelési technológia, az alacsony munkaerő-költségek) és a vállalati méretek közötti kapcsolatokat ellenőriztük. 2011-2013ban egyik tényező kapcsán sem találtunk szignifikáns öszszefüggést, ám 2015-2016-ban az egyik változó, a termelési technológia kapcsán már igazolható volt a szignifikáns kapcsolat (Khi négyzet: 9,561, df: 4, szign.: 0,047, p<0,05, igaz a phi érték nem mutat erős összefüggést: 0,208). A 15. táblázat e változó és a vállalati méret kereszttábla eredményeit tünteti fel.

Az adatokból jól látható, hogy a 250 föt, vagy annál kevesebb alkalmazottat foglalkoztató leányvállalatok esetében kevésbé jellemző e sikertényező érvényesülése, mint az ennél több munkavállalót foglalkoztató szervezeteknél.

A (leány)vállalat mérete szerinti elemzés a központi
HR-szerepeket sem a 2011-2013-as, sem a 2015-2016-os vizsgálati mintában nem jelezte szignifikánsan eltérőnek. Hasonló eredményt kaptunk a HR-döntésekért viselt elsődleges döntéshozatali felelösségnél is.

15. táblázat

A termelési technológia mint sikertényező a vállalati méret dimenziójában (2015-2016)

\begin{tabular}{|l|c|c|c|c|}
\hline \multirow{2}{*}{ Létszám } & \multirow{2}{*}{ Jellemzők } & \multicolumn{2}{|c|}{ Termelési technológia } & \multirow{2}{*}{ Összes } \\
\cline { 3 - 5 } & & Nem & Igen & \\
\hline \multirow{2}{*}{$1-250$} & $\mathrm{~N}$ & 71 & 30 & 101 \\
\cline { 2 - 5 } & $\%$ & $70,3 \%$ & $29,7 \%$ & $100,0 \%$ \\
\hline \multirow{2}{*}{$251-1000$} & $\mathrm{~N}$ & 31 & 32 & 63 \\
\cline { 2 - 5 } & $\%$ & $49,2 \%$ & $50,8 \%$ & $100,0 \%$ \\
\hline \multirow{2}{*}{$1001-2000$} & $\mathrm{~N}$ & 11 & 13 & 24 \\
\hline \multirow{2}{*}{$2001-5000$} & $\%$ & $45,8 \%$ & $54,2 \%$ & $100,0 \%$ \\
\hline \multirow{2}{*}{ több mint 5000 } & $\mathrm{N}$ & 14 & 10 & 24 \\
\cline { 2 - 5 } & $\%$ & $58,3 \%$ & $41,7 \%$ & $100,0 \%$ \\
\hline \multirow{2}{*}{ összes } & $\mathrm{N}$ & 6 & 5 & 11 \\
\cline { 2 - 5 } & $\mathrm{N}$ & $54,5 \%$ & $45,5 \%$ & $100,0 \%$ \\
\cline { 2 - 5 } & $\%$ & $59,6 \%$ & $40,4 \%$ & $100,0 \%$ \\
\hline
\end{tabular}

Forrás: a szerzők saját szerkesztése

A kritikus HR-területeket a szervezeti mérete tükrében vizsgálva ANOVA elemzéssel, 2011-2013-ban a képzés és fejlesztés területén mutattak szignifikáns eltérést $(\mathrm{F}: 2,476$, df: 4, szign.: 0,045, p<0,05). A 250 fönél kisebb szervezetek könnyebben birkóztak meg a képzéssel és fejlesztéssel, mint a nagyobb méretüek. 2015-2016-ban megfigyelhető, hogy a szórás nő, a területek kritikusságának átlagos szintje csökken és határozottan kiemelkedik közülük a mára már nemcsak a leányvállalatok, hanem a helyi cégek által is széleskörủen észlelt kritikus HR-terület: $a$ toborzás-kiválasztás nehézségei. A kritikus HR-területeknél megállapítható még, hogy míg az 5.000 fö feletti cégek jellemzően könnyen találnak fizikai munkaerőt vélhetően a munkaerő-közvetítő és -kölcsönző cégek bevonásával, addig a kisebb cégeknek ez nagyobb probléma. Igaz, a jól képezett müszaki dolgozókat tekintve már a nagy cégek sem érzik magukat könnyű helyzetben, hisz munkaerőhiány van a magasan képzett szakemberekben, melynek köszönhetően folyik a harc a tehetségekért. Az idegen nyelvü tudással rendelkező dolgozók megtalálása a cégek többségének mérettől függetlenül viszonylag kevésbé jelent gondot és hasonlóan vélekednek a tehetségek megtartásáról is. A versenyképes jövedelem biztosítása a 2.000 fönél kevesebb munkavállalót foglalkoztató cégek 60\%-nál jól müködik. A szakszervezetek befolyása pedig alapvetően az 5.000 fö felett müködő szervezeteknél volt jellemző. A HR-vezetői kompetenciák közül a személyes hitelesség valamennyi vállalati méretnél kiemelendő fontosságú volt.

Az előzőekben leírtak alapján a $\mathrm{H} 3$ hipotézist részben tartjuk igazoltnak. 
Az előzőekben leírtakból kitűnik, hogy mindhárom hipotézisünket részben sikerült alátámasztani. Ez arra utal, hogy a HR-kérdésekre adható válaszok nagyon összetettek lehetnek, és számos tényezőtől függnek. Az anyavállalat eredete, az anyaország menedzsmentkultúrája, a leányvállalat müködési ágazata, valamint mérete kétségkívül befolyásolja a vizsgált cégek HR-gyakorlatát, noha szignifikáns kapcsolatot csak néhány esetben találtunk.

\section{Zárógondolatok}

A jelen írás egy átfogó, több éves kutatás néhány eredményét mutatta be. A felmérést három egymást követő időszakban végeztük el, a mostani tanulmány két időszakasz vizsgálati eredményeit mutatta be. A vizsgálat során a mintagyüjtési eljárás hólabdamódszer volt, így habár a kutatás nem tekinthető reprezentatívnak, ám a szerzők úgy vélik, hogy jól mutatják a részt vevő országokban müködő szervezetek HR-jellemzőit.

Jól látható, hogy a válság felhőinek eloszlásával a növekedési és piacbővítési stratégia vált meghatározóvá a cégek közel háromnegyede számára. A képzési és fejlesztési költségek nem változtak érdemben, mind a két időszakban a leányvállalatok nagyjából 1/3-a 3\% feletti képzési költségkerettel rendelkezett, azaz erre a válságból való kilábalás nem hatott érdemben. Az eredmények egyértelműen megmutatták a kelet-közép-európai országok munkaerőpiacának erősödő problémáit is: habár a cégek számára változatlanul a legfontosabb stratégiai sikertényező a minőségi munkaerő biztosítása, egyre nehezebben találják azt meg, és a toborzás/kiválasztás vált a legkritikusabb HR-területté. A leányvállalati HR-müködésben egyre inkább elötérbe került a decentralizáció, a nagyfokú döntési és végrehajtási szabadság egyre több cégre jellemző.

Az eredmények tükrében a szerzők azt látták, hogy a külföldi cégek eredete, az anyavállalat országának (menedzsment)kultúrája, a cég profilja, fő müködési ágazata, a külföldi tulajdonú cégek, (leány)vállalatok mérete befolyásolja ugyan a leányvállalatok HR-jellemzőit, ám azok időben csak kismértékben módosuló alakulásában egyéb külső és vagy belső kontingenciafaktorok hatása is megjelenik.

\section{Korlátok és jövőbeli tervek}

A kutatásunk benchmarking (Evans, 1977) jellegű így magán viseli az ilyen vizsgálatok számos előnyét ( $\mathrm{pl}$. viszonylag kis költségü, azt mutatja, hogy másokhoz képest a résztvevők gyakorlata mit mutat) és hátrányát (pl. nem reprezentatív) is. Fontos utalni arra, hogy ezt a vizsgálatunkat eddig már három alkalommal (2008-2009, 2011-2013 és 2015-2016) ${ }^{3}$ végeztük el. Az első vizsgálat után kérdőívünk valamelyest módosult, ezért a mostani cikkünkben csak két utóbbi időszak (2011-2013 és 20152016) adatait tudtuk az elemzésünkhöz felhasználni. A mintáink méretei ugyan korlátozottak, mivel azonban már három alkalommal végeztük el ezt a felmérést - amiből a mostani elemzésben a két utolsó vizsgálat adatai szerepelnek - megfelelő áttekintéssel (Poór - Farkas, 2012,
2014; Poór et al., 2014b) rendelkezünk a multinacionális vállalatok helyi leányvállalatainál folyó HR-tevékenységek jellemzőiről.

Tervezzük, hogy a felmérésünket a mostani kérdöívvel 2018 tavaszán újra megismételjük, melynek sikeres lebonyolításától eredményeink longitudinális jellegének erősödését is várjuk.

\section{Jegyzet}

${ }^{2}$ www.ceeirt-hrm.eu

${ }^{3}$ Lásd bővebbe a www.ceeirt-hrm.eu web felületen

\section{Felhasznált irodalom}

Amable, B. (2003): The Diversity of Modern Capitalism. Oxford: Oxford University Press

Bakacsi Gy. (2014): A kulturális ingahatás. Vezetéstudomány, 45. (3), p. 4-18.

Bartlett, C. A. - Ghoshal, S. (2000): Transnational Management: Text, Cases and Readings in Cross-border Management. Boston: Irwin/McGraw-Hill

Beer, M. - Spector, B. - Lawrence, P. R. - Quinn Mills, D. - Walton, R. E. (1984): Managing Human Assets. New York: Free Press

Bogár L. (2012): Globalo-büntiben. Budapest: Kairosz Kiadó

Brewster, C. - Mayrhofer, W. - Morley, M. (eds.)(2004): New Challenges for European Human Resource Management. London: Macmillan

Brewster, C. - Bennett, C. V. (2010): Perceptions of business cultures in Eastern Europe and their implications for international HRM. The International Journal of Human Resource Management, 21. (14), p. 2568-2588.

Brewster, C. - Hillar, H. (eds.) (1999): International HRM. London: Routledge

Brewster, C. - Morley, M. - Buciuniene, I. (2010): The reality of human resource management in Central and Eastern Europe. Baltic Journal of Management, (5), p. 145-155.

Brodbeck, F. - Frese, M. - Bakacsi Gy. et al. (2000): Cultural Variation of Leadership Prototypes Across 22 European Countries. Journal of Occupational and Organizational Psychology, 73, p. 1-29.

Cleveland, N. J. - Byrne, S. Z. - Cavanagh, M. T. (2015): The future of HR is RH: Respect of Humanity at work. Human Resource Management Review, (25), p. 146161.

Csath M. (2008): Globalizációs végzetek. Budapest: Kairosz Kiadó

Csillag S. (2014): Az emberierőforrás-menedzsment mint morális útvesztő: Etikai kérdések az emberierőforrás-menedzsment tevékenységben. Budapest: BGFEmberi Erőforrások Minisztériuma

Dicken, P. (2011): Global shift. Mapping the changing contours of the world economy. London: SAGE

Dowling, P. J. - Festing, M. - Engle, A. D. (2013): International Human Resource Management. London: South-Western CENGAGE Learning 
Dowling, P. J. - Schuler, R. S. (1990): International Dimensions of Human Resource Management. London: PWS-KENT Publishing Company

Drucker, P. (1973): Management. New York: Harper \& Row Publishers

Dunning, J. H. (1992): The Globalisation of Business. London: Routledge

Evans, A. (1977): Benchmarking. Budapest: Közgazdasági és Jogi Könyvkiadó

Evans, P. - Pucik, V. - Barsoux, J. (2002): The Global Challenge: Frameworks for International Human Resource Management. Homewood: McGraw-Hill/Irwin

Fatehi, K. (1996): International Management: a cross cultural approach. Upper Saddle River, NJ: Prentice Hall

Fayerweather, J. (1978): International Business Strategy and Administration. Cambridge (Mass.): Ballinger Publishing Co.

Fombrun, C. J. - Tichy, N. M. - Devanna, M. A. (1984): Strategic Human Resource Management. New York: John Wiley

Gilbersons, S. H. (1950): Personnel Policies and Unionism. Boston: Gian and C.

Gomez-Mejia, L. - Balkin, D. - Cardy, R. (2014): Managing Human Resources. Harlow: Pearson Education Limited

Gupta, V. - Hanges, P. J. - Dorfman, P. (2002): Cultural clusters: methodology and findings. Journal of Word Business, 37, (1), p. 11-15.

Hall, P. A. - Soskice, D. (2001): An Introduction to the Varieties of Capitalism. In: Hall, P. - Soskice, D. (eds.) (2011): Varieties of Capitalism: The Institutional Basis of Competitive Advantage. Oxford: Oxford University Press

Hazing, A. W. - Sorge, A. M. (2003): The relative impact of country-of-origin and universal contingencies on internalization strategies and corporate control in multinational enterprises: Word-wide and European perspectives. Organisation Studies, Vol.24. No.2., p.187-214.

Hill, W. (2015): International Business. New York: McGraw-Hill

Hiltrop, J. M. (1991): Human Resources Practices of Multinational Organizations in Belgium. European Management Journal, 4., p. 404-411.

Hofstede, G. (1980): Culture's Consequences: International Differences in Work - Related Values. Thousand Oaks: SAGE

Hofstede, G. (1991): Cultures and Organizations. Software of the Mind. New York: McGraw-Hill

Hoós, J. (2000): Globalisation, Multinational Corporation and Economics. Budapest: Akadémiai Kiadó

Horowitz, M. F. (2011): Future HRM challenges for multinational firms in Eastern and Central Europe. Human Resource Management Journal, 21., (4), p. 432-443.

Inglehart, R. - Baker, W. E. (2000): Modernization, Cultural Change, and the Persistence of Traditional Values. American Sociological Review, 65, p. 19-51.

Ivancevich, M. J. (1995): Human Resource Management. Chicago: IRWIN
Karoliny M-né - Poór J. (2013): A HR-gyakorlatok alakulásának összehasonlító vizsgálata a világ négy régiójában, közép-kelet-európai sajátosságokat keresve. Competitio, 12(2), p. 20-38.

Karoliny M-né - Balogh G. (2017): A vertikális és horizontális integráció rendszere: EEM-stratégia, tervrendszer, értékelés és kontrolling. In: Karoliny M-né - Poór J. (2017): Emberi erőforrás menedzsment. (6. kiadás). Budapest: Complex-Walters Kluweer, p. 397431.

Karoliny M-né (2017): Áttekintés az emberi erőforrás menedzsmentröl. In: Karoliny M-né - Poór J. : Emberi erőforrás menedzsment. (6. kiadás). Budapest: Complex-Walters Kluweer, p. 23-60.

Kazlakauiste, R. - Buciunine, I. - Poór, J. - Karoliny, Zs. - Alas, R. - Kohont, A. - Szlávicz, Á. (2013): Human Resource Management in the Central and Eastern European Region. In: Parry, E. - Stavrou, E. - Lazarova, M. (eds.): Global Trends in Human Resource Management. London: Palgrave-Macmillan, p. 103121.

Koopman, P. L. - Den Hartog, D. N. - Konrad, E. - Bakacsi, Gy. (1999): National Culture and Leadership Profiles in Europe: Some Results from the GLOBE Study. European Journal of Work and Organizational Psychology, Special Issue on Organizational Culture, 8. (4), p. 503-520.

KSH (2016): Foreign Owned Companies in Hungary (2008-2014) http://statinfo.ksh.hu/Statinfo/haViewer. jsp?lang=en (Letöltve: 2016. December 10.)

Lawler, J. J. (2006): Cultural and Institutional Determinants of HR Systems in International Affiliates of American Multinational Corporations. Institute of Labor and Industrial Relations. Illinois: University of Illinois

Lewis, P. C. (2005): How the East was won. New York: Palgrave Macmillan

Meleg A. (2004): A globális munkás végtelenség. Népszabadság, november 24., p. 12.

Mintzberg, H. (2004): Managers not MBAs. San Francisco: Berret-Koehler Publishers

Morley, M. - Poór, J. - Heraty, N. - Pocztowski, A. (2016): Developments in Human Resource Management in Central and Eastern Europe in Comparative Perspective. In: Dickmann, M. - Brewster, C. - Sparrow, P. (eds.) (2016): International Human Resource Management. Contemporary human resource issues in Europe. London: Routledge, p. 75-99.

National Bank of Romania (2009): Foreign Direct Investment (FDI) in Romania in 2009. National Bank of Romania. Bucharest

National Bank of Romania (2016): Foreign Direct Investment in Romania in 2015. Bucharest

National Bank of Slovakia (2015): Preliminary data. http:// www.nbs.sk/sk/statisticke-udaje/statistika-platobnej-bilancie/priame-zahranicne-investicie (Letöltve: 2017. Január 20.)

Paauwe, J. (2004): HRM and Performance: Achieving long term viability. Oxford: Oxford University Press 
Perlmutter, H. V. (1969): The Tortuous Evolution of the Multinational Corporation. Columbia Journal of World Business, January-February, p. 9-18.

Poland in Figures 2015 (2015): Zakład Wydawnictw Statystycznych, Warsaw

Polónyi I. (2011): A külföldi tőke és a munkaerő szerepe. Educatio, 2., p. 139-149.

Poór J. - Farkas F. - Szlávicz Á. - Kerekes K. - Szabó K. (eds) (2014c): Emberi erőforrás menedzsment külföldi tulajdonú cégek helyi leányvállalatainál Közép- és Kelet-Európában 2011-2013. Gödöllő - Pécs - Révkomárom

Poór J. - Farkas F. (2012): Átalakuló emberi erőforrás menedzsment multinacionális cégek helyi leányvállalatainál Közép- és Kelet-Európában. Pécs: Pécsi Tudományegyetem

Poór J. (2013): Nemzetköziesedés és globalizáció az emberi erőforrás menedzsmentben. Budapest: Complex Kiadó Jogi és Üzleti Tartalomszolgáltató Kft.

Poór J. - Farkas F. (2014): Emberi erőforrás menedzsment külföldi tulajdonú cégek helyi leányvállalatainál Közép- és Kelet-Európában. Pécs: Pécsi Tudományegyetem

Poór J. - Karoliny Zs. - Dobrai K. - Slavic A. - Kerekes K. - Farkas F. - Engle, A. D. Sr. (2014b): Factors Influencing Human Resource Management Solutions at Subsidiaries of Multinational Companies in Central and Eastern Europe. Journal of East-West Business, 20. (1), p. 1-27.

Poór J. - Kovács I. É. - Karoliny M-né - Milovecz Á. (2014c): Külső HR-szolgáltatók összehasonlító vizsgálata a világ régiójában közép-kelet-európai sajátosságokat keresve, két Cranet felmérés alapján. Vezetéstudomány, 45. (10), p. 17-29.

Poór, J. -Engle, A. D. - Kovács, I. É. -Slavic, A. - Wood, G. - Szabó, K. - Stor, M. - Kerekes, K. - Karoliny, Zs. - Alas, R. - Némethy, K. (2015): HR Management at Subsidiaries of Multinational Companies in Central-Eastern Europe in Light of Two Surveys of Empirical Research in 2008 and 2013. Acta Polytechnica Hungarica - Journal of Applied Sciences, Vol.12. (No.3.), p. 229-249.

Poór J. (2016): Nemzetközi emberi erőforrás menedzsment. In: Blahó A. - Czakó E. - Poór J. (2016): Nemzetközi menedzsment. Budapest: Akadémia Kiadó, p. 282-300.

Poór József- Csehné Papp Imola - Kollár Péter - Lajos Attila - Jarjabka Ákos - Márta Anette - Varga Erika (2017): Az emberi erőforrás menedzsment befolyásolói és mozgatórugói. In: Karoliny M-né - Poór J.: Emberi erőforrás menedzsment. (6. kiadás) Budapest: Complex-Walters Kluweer, p. 61-91.

Psychogios, A. - Wood, G. (2010): Human Resource Management in Greece in Comparative Perspective: Al- ternative Institutionalist Perspectives and Empirical Realities. International Journal of Human Resource Management, 21(14), p. 2614-2630.

Pundziene, A. - Bučiūnienè, I. (2009): Managing human resources in Lithuania. In: Morley, M. J. - Heray, N. - Michailova, S. (eds.) (2009): Managing Human Resources in the Transition Economies of Central and Eastern Europe. Global HRM Series. London: Routledge, p. 55-90.

Reeb, D. - Sakakibara, M. - Mahmood, I. P. (2012): From the Editors: Endogenety in international business research. Journal of International Business Research, 43., p. 211-218.

Rees, C. - Edwards, T. (2003): HR's Contribution to International Mergers and Acquisitions. London: The Chartered Institute of Personnel and Development

Ronen, S. - Shenkar, O. (1985): Clustering countries on attitudinal dimensions: a review and synthesis. Academy of Management Review, Vol.10, No.3., p. 435-454.

Rowley, Ch. - Wei, Q. J. - Warner, M. (2015): Approaches to International Human Resource Management. In: Harzing, A. W. - Pinnington, H. A. (2015): International Human Resource Management. Los Angeles: SAGE, p. 106-142.

Schumpeter, J. (1950): Capitalism, Socialism and Democracy. London: Harper and Row

SIEPA (Serbia Investment and Export Promotion Agency) (2014): Beograd

Storey, J. (1995): Human Resource Management. London: Routledge

Tarique, I. - Briscoe, R. D. - Schuler, S. R. (2016): International Human Resource Management: Policies and Practices for Multinational Enterprises (Global HRM). New York: Routledge

Thomas, C. D. - Lazarova, B. M. (2014): International Human Resource Management -Managing People Globally. Los Angeles: SAGE

Tidd, J. - Bessant, J. (2013): Managing Innovation. Chichester: Wiley

Torrington, D. - Hall, L. - Taylor, S. - Atkinson, C. (2014): Human Resource Management. Harlow: Pearson Education Limited

Tung, L. R. (2016): New perspective on human resource management in a global context. Journal of World Business, 51., p. 142-152.

Tung, R.L. (1981): Selection and Training of Personnel for Overseas Assignments. Columbia Journal of World Business, 16 (1), p. 68-79.

Ulrich, D. - Dulebohn, J. H. (2015): Are we there yet? What's next for HR? Human Resource Management Review, 25. (2.), p. 188-204.

WIR (2016): World Investment Report 2016. New York: United Nations 